NEW LITERARIA-

An International Journal of Interdisciplinary Studies in Humanities

Volume 3, No. 1, January-February, 2022, PP. $72-81$

ISSN: 2582-7375

DOI: https://dx.doi.org/10.48189/nl.2022.v03i1.008

www.newliteraria.com

\title{
Learning Culture Through Play: A Brief Study of Nuchhungi's Mizo Naupangte Infiamna leh a Hla Te
}

\section{Lalthangmawii Chhangte \& KC Lalthlamuani}

\begin{abstract}
Every culture has its own collection of children's games and songs. "These children's games and rhymes and jokes do not exist in isolation: they have echoes in history, anthropology, archeology, literature, popular culture, and art." (Lurie 189) Collectors of children's games and scholars of children's literature have found similarities or connections between games that are played in playgrounds today and customs of the pagan folks of long ago. Mizo children have a variety of singing and non- singing games which have been handed down from generation to generation. Since in the olden times there were no schools, these games were the main engagements of young children. Some of them must have been among the oldest songs of the Mizo culture.

Nuchhungi's book, "Mizo Naupangte Infiamna leh a Hla Te", a collection of indigenous games and their accompanying songs commonly played by Mizo children, contains more than seventy singing and non-singing games, forty three traditional children's songs, and fifteen lullabies. The songs and games collected in this book represent the popular pastimes of Mizo children at different times in history. They provide insight into the life of Mizo children of the past generations who indulged in these pastimes, of the adults' treatment of them, and of their place in the social hierarchy. Some of the games that have been collected are mimetic representations of adult activities and so inform the present generation of the folk way of life. This paper attempts to look at the ways in which folk culture has been depicted in the indigenous games and songs of Mizo children
\end{abstract}

Keywords: Culture, Indigenous Games, Children's Songs, Play.

The playground is one of the most important settings where children learn to create a shared folk culture. According to Sylvia Grider, the playground is "a microcosm - a laboratory in which we can learn a great deal about processes and functions of tradition." (Grider, 1980, p.162) Play may be defined as a voluntary and often spontaneous activity for the purposes of recreation, learning, and spending excess energy. Games are a prime outlet of the play urge in children, an urge which is universal. Hence, for children, games are, first of all, recreation, a way of passing time pleasantly and constructively.

But games are more than just recreation. They serve as "cultural indicators and active agents of socialization." (Christenson, 1987, p. 51) Studies on children's lore are revealing the universality and the antiquity of the rhymes, jokes, games, and superstitions which make up children's folklore. They embody dominant cultural values and patterns of social behavior of different epochs in history. Hence, the process of collecting and recording games is valuable 
because it can tell us about the culture under study as well as about the meaning and activities involved in the games themselves. (Christenson, 1987, p.51)

Every culture has its own collection of children's games and songs. "These children's games and rhymes and jokes do not exist in isolation: they have echoes in history, anthropology, archeology, literature, popular culture, and art." (Lurie, 1990, p. 189) Collectors of children's games and scholars of children's literature have found similarities or connections between games that are played in playgrounds today and customs of the pagan folks of long ago. The Mizo too has a variety of singing and non- singing games played by children. Among them, some have been handed down from generation to generation. Since in the olden times there were no schools, these games were the main engagements of children who were too young to work in the jhum fields. Some of the lullabies and singing games like Pawnto Hla (pawnto songs) and Pipu Uai Hla (songs sung while playing on the swing) must have been some of the oldest songs of the Mizo culture. RL Thanmawia is of the opinion that these children's songs must have been sung by children in ancient times (Thanmawia, p. 27)

Nuchhungi's book, Mizo Naupangte Infiamna, which was a collection of games and their accompanying songs commonly played by Mizo children, was jointly published in 1965 by the Assam publication board and Mizo Academy of Letters (MAL) and printed in JB Press, Lunglei. An enlarged edition of this book was published in 1994 and the title was changed to "Mizo Naupangte Infiamna leh a Hlate." The collection contains more than seventy singing and non-singing games, forty three traditional children's songs, and fifteen lullabies. The songs and games collected in this book represent the popular pastimes of Mizo children at different times in history. They also provide insight into the life of Mizo children of the past generations who indulged in these pastimes, of the adults' treatment of them, and of their place in the social hierarchy. Some of the games that have been collected are mimetic representations of adult activities and so inform the reader of the folk way of life.

Life was not easy for the folk in the olden times. Adults in the family had to work all day in the jhum, and in addition to that women had the added task of doing all the household chores. They were fully occupied from early morning till late at night. During the daytime, villages were empty of people except for children, old people, and the infirm. Children were left much to their own devices. The older girls took on the task of looking after the babies and toddlers and performing simple household chores.

Nauawih Hlate, the Mizo lullabies sung by young girls who babysit their siblings while their parents work in the fields showcase many aspects of the Mizo culture and tradition. Young girls looking after their younger siblings take them along in their play and sing lullabies to them when they get drowsy or fretful. These lullabies were most probably composed by adults but because they were composed to be sung to little children, they are usually included in children's literature. Lullabies are usually simple songs, at times nonsensical, but they also tell of the folk's lifeways, worldviews, folktales, and their myths and legends.

A number of Mizo lullabies in Nuchhungi's collection allude to past events in the life of the Mizo folk, to the places they left behind in the course of their migration, the folk belief in the afterlife, and the rite of passage of a deceased soul. They also tell of the social customs and practices of the folk. Lullabies are sometimes nonsensical, other times they are also renderings of folkways, folk worldviews and folktales. An example is the following couplet which goes,

An lal fanu Chhingi Zathum an chhiar e,

Zathum man chu keiin lei rual em ni le? (Nuchhungi, 1994, p. 82) 
Their chief's daughter Chhingi is priced three hundred,

Can one such as I afford three hundred? (my trans.)

This couplet depicts the social hierarchy of the Mizo society. In Mizo tradition, brideprice is handed over as part of a marriage alliance. The daughters of Mizo Chiefs were priced much higher than other young women and it was very difficult for commoners to pay such an exorbitant amount of money as bride-price. Moreover, matches were usually arranged between children of Mizo Chiefs and it was only on rare occasions that exceptionally brave and handsome commoners could win the hand of the village Chief's daughter. In Mizo folktales are found tales of forbidden love between the daughters of Chiefs and handsome young commoners or the son of a Chief and a beautiful but poor maiden which end in tragedy.

Nostalgia for the past is a prominent feature of Mizo folk songs and this is also reflected in the lullabies. The folks had, in the past, settled on the banks of the river Run and the culture's memory of this past era is projected in their repeated mention of the river Run. The frequent invocation of the Run has caught the children's imagination that they invoke the river in their songs for the little ones:

Khawpui ri dur dur e, van rial a chim e,

Ka nauvi kal nan e, runtui a lian e.(Nuchhungi, 1994, p. 73)

The roaring thunder brings, a storm of rain and hail,

The swollen Run is too strong to cross, my child. (my trans.)

In the course of their migration, the Mizo tribes had had to struggle not just against inhospitable terrains but also against invasion by other tribes or races. In such circumstances they looked to the strong, ingenious, and courageous warriors for their deliverance. As such, the pasaltha (brave warriors who were accomplished in warfare and hunting) were held in high esteem. Hence, the valourization of the warrior finds its expression in the many folksongs of the Mizos and even in the lullabies sung for babies and little children.

A khi ah khian rammu an kal dial dial e,

Ka nauvi pa tel ve maw ral that ve maw.(Nuchhungi, 1994, p. 82)

Up yonder the warriors go marching,

Is my child's father among them, killing the foes? (my trans.)

The apparently simple lullabies reveal the Mizo ancestor's belief in the immortality of the soul:

Mitthi an kal zo ve, an run an pel e,

Rihtlang an liam zo ve, hring lam ngai ve maw.(p. 82)

Gone are the dead leaving their earthly abode,

Gone beyond Rih Mountain, do they pine for life? (my trans.)

The Mizo believed that the departed souls have to cross the Rih lake on their way to reach Pialral (Paradise for the Thangchhuah) or Mitthikhua (Abode of the dead), whichever afterlife the souls are destined for. The Mizo's preoccupation with the afterlife is depicted in this short musing on whether the soul longs for the life it has left behind.

The values and life ways of the folks oftentimes find expression in their lullabies:

A khi tlang sang puiah tiandar a ri $e$,

Laltean sai a kap an sai lu lam e.(p. 82)

High upon the hill the gong reverberates,

Laltea has shot an elephant, the trophy is being feasted. (my trans.) 
Sa lu lam is a proud occasion for a man who has killed a ferocious beast that would help him achieve thangchhuah and thereby ensure his passage to pialral. The kill is met with much fanfare and the whole community celebrates with a feast. Children look forward to these occasions as much as the adults and this is reflected in the songs they sing for the little ones.

The songs sung to put little children to sleep therefore, are not merely the nonsensical kind, for, as mentioned above, there are a number of couplets that portray the history, life ways, values, and the eschatological belief of the Mizo folk.

Representation of children in Mizo literature corroborates historical accounts that children occupied an inconsequential place in the social hierarchy of the Mizo society in the olden days. The fact that they were not welcome in adult company is highlighted by the oft quoted dismissal, "Naupangte kha kal kiang rawh u,uite rim in nam." "You children smell like puppies, get yourselves off." (my trans.) Most of the time, therefore, children were left to themselves. They learnt to fill these moments with recreational activities. One such activity is called Pawnto, the favourite pastime of Mizo children. Children would rush out of their homes to play soon after finishing their supper. They would call their friends to come out and play

Pawnto is a special time for children since it gives them license to take part in their own cultural practices away from the watchful, often critical eyes of the adults. This cultural space shared exclusively by children has given birth to many games and songs which have become part and parcel of the Mizo children's folklore.

Nuchhungi has documented a number of pawnto games which are mostly singing games. Among the pawnto songs is one that goes;

Ka thian (hming) lo chhuak rawh,

Zu chu zu chu kan nei lo naa, lam kan thai dawn e.

Khuang kan beng dawn e (sumtualah)

Pim, pim, pim.(Nuchhungi, 1994, p. 76)

Come out my friend, (name),

Though we have no $z u$ (rice beer), we are going to dance.

We are going to beat the drum (in the courtyard)

Pim, pim, pim. (my trans.)

This call to play depicts one of the many ways in which children mimic their elders. An important practice of the Mizo tribes was $A i$, or $S a a i$, which was a feast or ceremony, a sacrifice connected with hunting and killing animals. "The practice was the result of a belief that if $A i$ sacrifices are performed it would enable the spirit of the slain animals to remain servants of the hunter in the afterlife. And if the $A i$ sacrifice is not performed the spirit of the deceased animals would haunt the hunter throughout his life." (Malsawmdawngliana, 2015, p. 157) At first the $A i$ sacrifice was simple, involving only relatives and neighbours of the hunter. In time it developed into a grand feast for the entire community, and a night of drinking and dancing for the adults in the village. Children could eat at the feast but they could not participate in the revelry that followed so they would parody in their play the drinking and dancing to which they were forbidden.

Special occasions in the community were, and still are a source of great excitement for children:

Ka kawmchhak leh chhawng a min,

Nghalpa zuksial an ai e. 
Ruai theh kan dawng chek chek e,

Chibai.(Nuchhungi, 1994, p. 8)

Just two rows above our house,

Cooks the boar,the mithun, and the deer.

The smell of feast comes wafting down.

Greetings. (my trans.)

The customary community feast to celebrate the kill of dangerous beasts by killing domestic animals and feasting was an event that was accompanied by much fanfare. Though deer were not included among the ferocious beasts, the folk believed that killing these animals brought good fortune to the hunter; hence their killing was also celebrated in the same manner as the killing of the ferocious predators. On the day of the celebration men would spend the day drinking rice beer after which the whole community would have a feast. This occasion is somewhat similar to Khuangchawi and differs only in the fact that Khuangchawi is an even more prestigious event. Children enjoy these occasions as much, perhaps, even more so than adults. Their excitement over the prospect of a feast is portrayed in the song above where children sing of sa aih and their anticipation of a good feast.

Bravery and chivalry were qualities that were valourized in the Mizo society. When a baby boy was born it was customary to utter, "Mi huaisen, sa kap thei" which means "a brave man, a good hunter" so that the baby would grow up to be a brave and courageous man. The wish to be strong and courageous was so ingrained in the children that they despised cry-babies. They would taunt their crying friends with the song,

Tah belh tah belh,

Arpuiin chu hlawk, chu hlawk,

A notein kaileng phar dawr dawr.(Nuchhungi, 1994, p. 74)

Cry baby, cry baby,

May the hen peck and peck you,

May the chicks drag you around. (my trans.)

Pawnto games are meant to be played by a group of children, so it no surprise that all the indigenous games that are in Nuchhungi's collection are group games. Nuchhungi has classified her collection of games in her own manner, taking into consideration the way in which the games are played, the number of players, the gender of the players, and so on. The games are divided into singing and non - singing games and are played in various ways. Some games involve holding hands and forming a circle, some are played by forming a line and following the leader, some games are played standing up while others are played sitting down. These games provide the growing mind and body with good exercise. They are also a means of learning social skills and passing on folk tradition.

In-Ulen is a series of singing games that can be played by two or more children. When playing this game children hold hands and stand in circle. Then they start singing and, still holding hands, they run with great speed. Some of the songs that are sung in accompaniment to this game are nonsensical while others are interspersed with folk customs and traditions, and folk worldview. For instance, lines from one of the songs go,

\author{
Khita hrui han chhat tang nge \\ Tu lu khai nan nan emaw \\ Chhimbuka lu khai nan nan emaw. (Nuchhungi, 1994, p. 1) \\ Let's cut the vine up yonder \\ To hang people's head with it
}


Or to hang an owl's head with (my trans.)

These lines which in their context seem nonsensical reveal a cultural practice that was widely prevalent in the pre-Christian Mizo society. The practice of beheading animals and enemies they have killed and hanging them up as trophies was something that even children were familiar with. Further down a few lines, the song goes,

Ka pu'n sial a chhun,

Ni khatah se li se nga a chhun.( p. 1)

My grandpa has speared a mithun

Not one but four and five in a day. (my trans.)

These lines refer to the practice of Khuangchawi, when a warrior prepares a feast for the whole village to celebrate his killing of certain prescribed ferocious animals. A person who can perform Khuangchawi is a brave warrior who has established his mastery over the animals by killing them. It is a matter of great pride and honour even for the children who can boast of relatives who have achieved such great feats. Another song sung while playing this game goes,

\author{
A tel dawn e, \\ Hnute um pui a tel dawn e, \\ Zak thei lo pui \\ A tel dawn e.(Nuchhungi, p. 2) \\ She's joining, \\ The one with the growing breast, \\ The shameless one, \\ She's joining. (my trans.)
}

Jay Mechling believes that children tend to organize themselves into different folk groups depending on their age or gender, and that this is a "powerful, limiting force on who shall constitute the child's folk peers." (Mechling, 1986, p. 96). The division of folk groups based on age seems to have been prevalent in the Mizo society in the past. The above song, which taunts an older girl for trying to join the play group for younger children, shows young children's resentment of the intrusion of an older girl in their play because she does not belong to their play group.

Some pawnto games have songs that narrate historical events or epochs:

Ngur kan lal lai

Sailo ngurpui kan lal lai

Kan thlek lel lel kan thlunglu

Kan vai riai riai kan chawn ban

Kan per chhek chhek kan phei khawng

Khawng leh zual.(Nuchhungi, 1994, p. 3)

Chiefs, we rule,

Sway our heads from side to side,

Wave our arms from side to side,

We stamp our feet the harder,

E’en harder! (trans. Lalthangliana, p. 115)

B Lalthangliana says, "Though this song was sung by children at play, the literature is of a high standard. The whole song describes the characteristics of the Sailo chiefs." (Lalthangliana 116). The Sailos were a brave clan that had established their might over many other clans. It is said that the first Sailo Chief ruled Tualte village in 1600. Since that period 
they began slowly expanding their reign to other villages so that in the following centuries they became acknowledged by other clans as the dominant ruling clan. The deceptively simple song not only showcases the pride and confidence of persons belonging to the Sailo clan but also suggests a social hierarchy based on clan and conflicts between clans in attempts to establish superiority.

A traditional game which is still popular among children today is Tira mei kaiah (Hold the mouse's Tail). The players drape a puan over one shoulder or around their waist and tie it at the back. Each player holds the end of the puan of the player in front of him or her. They form a long queue with the older and bigger players in front and the little ones in the rear. The leader bangs on a chhepchher (bamboo clapper) to keep the rhythm and the players follow the leader. Their pace quickens or slackens on the whim of the leader. As they happily hold on to the person in front and follow the leader, they repeatedly sing the song,

\author{
Tira mei kaiah ha ha \\ Chhimtira mei kaiah ha ha \\ A hnuhnung kha seh rawh, \\ Lailen te kha seh rawh. (Nuchhungi, 1994, p. 16) \\ Hold the mouse's tail, ha ha \\ Hold on to the mouse's tail, ha ha \\ Bite the last without fail, \\ Bite the little wagtail. (trans. Lalthangliana, p. 117)
}

Lalthangliana, in his book, Culture and Folklore of the Mizos refers to this as a game played by boys while Nuchhungi does not specify it as a gendered game in her collection. Today both girls and boys take part in the game. As the rules of this game demand that the players hold on to the puan of the person in front of them, and also to strictly follow the leader of the pack, it teaches the participants obedience to rules and to authority. According to Lalthangliana, "the game teaches the children to respect their elders.... to follow happily in the footsteps of their elders." (Lalthangliana, p. 117) In the traditional Mizo society young boys are taught and trained to wait on their elders and not to assume leadership unless told to do so. This game, therefore, is culturally significant as it reflects the code of conduct in the Mizo society.

The swing has been a prominent feature in the life of Mizo children since the olden times. Playing on the swing has always been a popular pastime for Mizo children, and for that matter, children around the world. Song sung while playing on the swing are called Pipu Uai Hla. Children would swing with great pleasure, up and down, up and down, and sing along in keeping with their movements:

Pipu kan suih, ram tinah kan suih, A sat chat tu mi u duai ngai lo.

Ka zuk thlir a Theite thuam hnuaiah,

Phunchawng Lalngo a tha sensiar e. (Nuchhungi, 1994, p. 83)

We make swings here, there, and everywhere,

The braver elders come to cut them off.

From my vantage point I spy, the pretty red phunchawng

Beneath the branches of a plum tree. (my trans.)

Another popular game in Nuchhungi's collection which seems to have variants in many other cultures is called Bingte Sairawkah. This game has certain similarities with the game 'Drop the Handkerchief' which is played in a number of countries. While this guessing game 
is in progress children sing an old song,

Bingte sairawkah,

Sairawkah leh chang panah

Piring parang kai kum dim diam

Tuana tuana ka se hawl rawh

Kaikum rawh, dim diam taka

Dim diam takah, hre thei rawh. (Nuchhungi, 1994, p. 22)

It is not easy to decipher this seemingly nonsensical song, much more to translate it, so the attempt at translation has not been made. Jay Mechling points out three elements that figure prominently in children's folk culture, parody, nonsense, and secrecy. These are used by children in the play frame "to establish a shared, expressive folk culture distinct from and often resistant to what they perceive as adult sense of order." (Mechling, 1986, p. 102-103) The song Bingte Sairawkah may be purely nonsensical but at the same it may also be a coded message as secrets may be very important and meaningful to children who form a relatively powerless folk group in the society.

It is difficult to draw the line between play and games. Though some scholars tend to relegate play to activities that do not have any rules in contrast to games that are played under a set of rules and are usually competitive, having losers and winners, others tend to use the words interchangeably. Most of the games that have been discussed so far are played under certain set rules but they are not competitive. The few non-singing games that have been documented by Nuchhungi are competitive in nature and are played by children who have developed a good mastery over their motor skills.

Invawr is a game that is played using five smooth round stones. It is difficult to ascertain when Mizo children started playing this game which seems to be a variant of similar games played in other parts of the world which go by various names like Jackstones, Chuckstones, Dibs, Dabs, Fivestones, Otadama, Tally, Knucklebones and so on. This game is said to have originated in ancient Asia in 1184 BC. (Singapore infopedia,) In all these variants the game is played with five round pebbles or with "five triangular or pyramidal shaped cloth bags filled with either sand, rice, or dried beans". (Singapore infopedia,) Invawr is a game that helps to improve concentration. It develops a child's dexterity and hand-eye coordination. The fact that the game is also played in a number of neighbouring Asian countries could be an indicator of the Mizo's close cultural affinity with these cultures. Further research on the game may yield useful information about the cultural history of the Mizo.

Inbah or Inkawibah is another competitive game played by Mizo girls. This game can be played in three ways: Bahpui, Bahte, and Insal Man. The rules of these games may vary from place to place. The game can be played by two or more players. The best way to play this game is in a big group. As this game involves skill, a player with a good aim is very much in demand for one player can keep the whole team in play for a long time. The boy's version of this game played with kawisis called Inkawihnawk. It differs from the girl's game in its rules and coupled with skill. Mastery of the game rests on strength, the ability to throw the kawi with great force. Besides the skills developed by playing these games these games teach the players the importance of teamwork not just in the playing field but for living with others in society.

Inbihruk Siak (Hide and Seek) and In Hming Hriat (Name Guessing) are games that were and still are popular among Mizo children as they are among children of other cultures. These games seem to be common to most cultures and need not be explained at length. 
The fact that most indigenous games of the Mizos are mostly played in groups suggests that since the olden times the Mizo society had always laid great emphasis on cooperation and team work. Individualism is a concept foreign to most tribal societies and in the Mizo society where kinship, fraternity, and selflessness are ideals that are valourized by the community, where the important events of an individual's life - birth, marriage, and death become community events, where the clearing and weeding of the jhum, and the harvesting of crops become a community effort, it makes complete sense that most of the games children engage in are games that teach the importance of these ideals they will live by when they reach adulthood. Hence, the playground has, since the olden times been an important place where the passing on of culture and tradition has taken place. Children have always been active participants in the preservation and conservation of a culture's practices and traditions. Their lore which is found in their play remains a treasure trove for scholars involved in culture studies and merits a more intensive exploration than has been done in this paper.

The final words on the importance of children's play in cultural studies may be summed up with the following couplet:

Sem sem dam dam,

Eibil thi thi. (Nuchhungi, 1994, p. 73)

Share, Share, live live,

Hoard, hoard, die, die. (my trans.)

This simple ditty sung by children in the olden times when sharing what they have with their friends sums up the whole ethos of the traditional Mizo society, that of sharing one's time, possessions, and skills with those in need. It was this tradition of selflessness and the prioritizing of the common welfare that had sustained the folks since ancient times, a code of conduct that still holds together the present Mizo society.

Knezevic believes that "traditional games are a part of the purest ethnological heritage which, with its archaic and original structure is passed on from generation to generation. They present a very important segment of overall traditional folklore." (Knezevic qtd. in Kovacevic, 2014, p. 9) Many traditional games of Mizo children have been lost and forgotten in today's world. There may be many reasons to account for the disappearance of these games, reasons which themselves stem from the changed cultural milieu of the Mizo. In the contemporary Mizo society, pawnto, or the unsupervised play of children in the evening is no longer encouraged mainly due to safety reasons and lack of space for play. Yet the preservation of traditional games is vitally important for the perpetuation of culture.

Growing up in the early colonial period and having played many of the traditional games as a child, Nuchhungi had firsthand knowledge of the games. During her own lifetime, due to the changes in the way of living, she witnessed the traditional games slowly losing their popularity among the children. In order to ensure that these games do not die out, she compiled a collection of the popular traditional children's games thus providing future researchers with a sizeable amount of raw data and also created conditions for learning these games by teaching them to her students in school as a part of their extracurricular education. Taking her cue, the Mizoram government and NGOs have revived these games at festivals and social gatherings. $\mathrm{Had}$ it not been for her foresight in recording and documenting a number of traditional children's games, many of them would have been lost to the present generation. 


\section{References}

Christenson, Peter. G. (1987). Collecting and Interpreting Playground Games: A Children's Museum Project. Children's Environments Quarterly, vol.4, no.1, Children's Museum, Spring, pp. 51 -54. www.jstor.org/stable/ 41514618.

Grider, Sylvia. (1980). The Study of Children's Folklore. Western Folklore, Vol. 39, No. 3, Children's Folklore (1980), pp. 159-169. Western States Folklore Society www.jstor.org/stable/1499798

Kovacevic, Tatjana \& Sinisa Opic. (2014). Contribution of Traditional Games to the Quality of Students' Relations and Frequency of Students' Socialization in Primary

Education. Croatian Journal of Education, vol. 16, Sp. Ed. no. 1, pp. 95 - 112.

Lalthangliana, B. (2005). Culture and Folklore of the Mizos

Lurie, Alison. (1990). Don't Tell the Grown-ups: The Subversive Powers of Children's Literature. Little, Brown and Company.

Malsawmdawngliana. (2015). Negotiating the Past: Memory History and Culture of Mizo. Scientific Book Centre.

Mechling, Jay. (1986). Children's Folklore. Folk Groups and Folklore Genres: An Introduction, edited by Elliot Oring. Utah State UP.

National Library Board, Singapore Infopedia - eresources.nlb.gov.sg > infopedia.

Nuchhungi. (1994). Mizo Naupang Infiamna leh a Hla Te. Baptist Assembly Press.

Thanmawia, R L. (2010). "Mizo Hla Chanchin." History of Mizo Literature, Department of Mizo, MZU. pp. $24-74$.

\section{$\underline{\text { Bio-note }}$}

Lalthangmawii Chhangte is an associate professor in the department of English, Govt. J Buana College, Lunglei. She is also a research scholar working under the supervision of Prof. KC Lalthlamuani. Her areas of interest include Ecocriticism and Culture Studies.

Prof. KC Lalthlamuani is currently the Head of Department, Department of English, Mizoram University, Aizawl. Her areas of interest include Post- Colonial Literature, Drama, Gender and Culture Studies.

Email Id: lalthangmawiic@gmail.com 